\title{
Sulphate reducing bacteria to precipitate mercury after electrokinetic soil remediation
}

\author{
${ }^{1}$ T. Håkansson, ${ }^{2 *}$ P. Suer, ${ }^{1}$ B. Mattiasson, ${ }^{3}$ B. Allard \\ ${ }^{1}$ Department of Biotechnology, Lunds University, Box 124, SE 22100 Lund, Sweden \\ ${ }^{2}$ Department of Geomaterials and Modelling, Swedish Geotechnical Institute, SE 58193 Linköping, Sweden \\ ${ }^{3}$ Department of Natural Sciences at Örebro University and the head of Man Technology Environment Research \\ Centre, Örebro University, Sweden
}

Received 7 January 2008; revised 29 January 2007; accepted 20 February 2008; $\quad$ avaiable online 10 March 2008

\begin{abstract}
Combined treatment with electroremediation and sulphate reducing bacteria (SRB) was tested in laboratory and pilot scale. The contaminated soil came from a chlor-alkali factory and contained about $100 \mathrm{mg} / \mathrm{kg} \mathrm{Hg}$. Iodide/iodine complexing agent was used to mobilize mercury. Mercury iodide complexes were moved to the anode solution using an electric field. The anode solution was then mixed with hydrogen sulphide $\left(\mathrm{H}_{2} \mathrm{~S}\right)$ containing water, causing precipitation of mercury sulphide. The $\mathrm{H}_{2} \mathrm{~S}$ was produced at site by a SRB reactor. Precipitation problems arising from the nature of the anode solution were expected, since this solution is highly acidic, very oxidised and may contain iodide/iodine that strongly complexes mercury and can hinder mercury sulphide precipitation. Mercury concentrations in the anode solution were up to $65.7 \mathrm{mg} / \mathrm{L}$ (field) and $15.4 \mathrm{mg} / \mathrm{L}$ (lab. scale). Reduction of mercury in the water was $>93 \%$ at all times. Iodide did not hinder the process: Nonetheless, in the lab system, iodide concentration was high in the anode solution but mercury reduction was $>99.9 \%$. The redox potential was sufficiently low for HgS precipitation during the experiments, except for a short period, when the mercury removal decreased to $94 \%$. Sulphate reducing bacteria are shown as a viable tool for the treatment of mercury contaminated, acidic, oxidative, iodide containing water, such as that produced by electrokinetic remediation. A second SRB step or other water treatment is required to reduce the mercury concentration to environmentally acceptable levels. Redox potential is the most sensitive factor in the system.
\end{abstract}

Key words: Hydrogen sulphide, in situ, on site, wastewater treatment, soil contamination, iodide

\section{INTRODUCTION}

Contamination of soils with mercury is a serious problem due to the high toxicity of the metal and its compounds. The Swedish government has decided that mercury should be removed from circulation and put in deep bedrock repositories. This necessitates the removal of mercury from contaminated soil, followed by removal from the process water and concentration of the mercury in a stable form, preferably cinnabar (HgS) (Naturvårdsverket 1997; Swedish governmental bill 1997/98).

One method to remove metals from contaminated soil is through electroremediation (Acar and Alshawabkeh 1993; Probstein and Hicks 1993; Reddy et al., 2001). An electric field may remove metals from clayey soils, as has been demonstrated in several field applications (Ho et al.,1999; Lageman and Pool 2001).

*Corresponding Author Email: pascal.suer@swedgeo.se Tel.: direct +4613 201889; Fax: +4613201914
Iodide, in combination with an electric current, has been used to mobilize mercury from contaminated soils (Cox eet al.,1996; Suèr and Lifvergren 2001; Suèr and Lifvergren 2003). The mercury must be removed from the aqueous solution subsequent to mobilization. This is complicated by the low $\mathrm{pH}$, high oxidising capacity and iodide/iodine content of the water. It can be carried out by sulphide precipitation, since mercury sulphide has low solubility even at low pH (Monhemius 1977). Sulphate reducing bacteria (SRB) produce hydrogen sulphide as a result of their respiration process (Jorgensson 1982; Hansen 1994; Hamilton 1998). The use of hydrogen sulphide to precipitate and thus remove metals from a water stream has been studied in different applications (Webb et al., 1998; Khan et al., 2004; Lloyd et al., 2004).

Laboratory scale and field scale electro-kinetic treatment of contaminated soil from a chlor-alkali factory 
site containing high levels of strongly bound mercury is reported in this paper. The strongly bound mercury is mobilized by iodide and transported with an electrical field, resulting in a mercury contaminated water with low $\mathrm{pH}$ and a very high oxidation level. The water is then collected and treated further with biologically produced hydrogen sulphide at site. The hydrogen sulphide is produced at site in a bioreactor. Different kinds of bioreactors for hydrogen sulphide production have been studied (Kolmert et al., 1997; Håkansson and Mattiasson 2002; Alvarez et al., 2006) with different kinds of carbon source (Barnes 1994; van Houten et al., 1994; Monserrate and Häggblom 1997; Kolmert 1999). The observed mobilization and precipitation are discussed.

\section{MATERIALS AND METHODS}

\section{Laboratory setup}

Soil

Several hundred kilograms of soil were taken from the site of a chlor-alkali factory. The soil was homogenized in a cement mixer. $29 \%$ of the soil particles was larger than $2 \mathrm{~mm}, 42 \%$ was sand and silt and $29 \%$ was smaller than $63 \mu \mathrm{m}$ (clay). The soil had a loss on ignition of $2.5 \%$, a sulphur content of $4 \mathrm{~g} / \mathrm{kg}$ and a $\mathrm{pH}$ in a water suspension of 7-7.5. Major elements were determined by XRF analysis, showing Si 20, Fe 3.3, Al 2.2, K 1.5, Ca 1.4 and Mg 0.06\%. Analysis by XRD indicated less than $10 \%$ crystalline minerals (mainly quartz, microcline and albite), while the remainder consisted of poorly defined clayish material of low crystallinity (illite). The mercury content was $94 \mathrm{mg} / \mathrm{kg}$ in the laboratory scale and $91 \mathrm{mg} / \mathrm{kg}$ in the field scale application. Mercury was highly immobile in this soil and was associated with organic matter and secondary sulphides (Lifvergren 2001). Other metal contaminants are described by Suer et al. (2003).

\section{Soil treatment}

The electro-remediation was set up as described by Suer and Lifvergren (2003) with lower electric field strength and iodide addition in order to approximate the field situation more closely. Homogenized soil (1.5 $\mathrm{kg}$ ) was sieved and a fraction with particle size $<2 \mathrm{~mm}$ was placed in an open plastic box between two polypropylene geotextile filters $27 \mathrm{~cm}$ apart. The filters kept the soil separated form the $10 \mathrm{~cm}$ long electrode compartments located at each side of the box. Electrodes (a titanium cathode and an iridium-coated titanium anode) were placed in the electrode compartments. Water (2 litres, 18MOhm) was distributed evenly over the soil and the electrode compartments with approximately 0.4 litre in each electrode compartment and 1.2 litre in the soil. The water levels in the electrode compartments were kept close to constant by means of a siphon to a tank for each compartment to prevent drying. The solution in the electrode compartments was continuously stirred.

Plastic syringes (without tips) were placed at 3.5 $7.5,12.5,17.7,22$ and $27 \mathrm{~cm}$ from the anode geotextile position. These were used for sampling and measurement. Potassium iodide (2g, analytical grade) was added to the cathode compartment. An electrical field corresponding to a potential of $10 \mathrm{~V}$ was applied (Fig. 1)

\section{SRB system}

A stirred tank reactor of $1 \mathrm{~L}$ volume with a suspended carrier biofilm with a mixed culture of SRB was used. The reactor was filled to $50 \%$ (v/v) with commercially available plastic carriers from Kaldnes Miljöteknologi A/S, Norway. The carriers were kept suspended with help of a magnetic stirrer. The SRB reactor was placed in series with a reaction tank with a volume of $150 \mathrm{~mL}$ where the $\mathrm{H}_{2} \mathrm{~S}$ rich outflow were mixed with the $\mathrm{Hg}$ contaminated anode water. Mixing was done with magnetic stirring and the water was then transferred to a settling tank $(150 \mathrm{~mL})$ where the precipitate was allowed to settle. The mixing was done 3:1 (v:v) $\left(\mathrm{H}_{2} \mathrm{~S}\right.$ water: mercury containing water) when the flow of water from the anode was $20 \mathrm{~mL} /$ day. After 4 days, a decrease in flow was observed but the mixing ratio was kept constant.

The SRB consortia were grown in $0.1 \mathrm{~g} \mathrm{Fe}_{2}\left(\mathrm{SO}_{4}\right)_{3}$; $1.17 \mathrm{~g}\left(\mathrm{NH}_{4}\right)_{2} \mathrm{SO}_{4} ; 0.1 \mathrm{~g} \mathrm{MgSO}_{4} * 7 \mathrm{H}_{2} \mathrm{O} ; 0.1 \mathrm{~g} \mathrm{CaCl}_{2} * 2 \mathrm{H}_{2} \mathrm{O}$; $0.1 \mathrm{~g}$ EDTA; $5.3 \mathrm{~g} 80 \%$ Na-lactate and $0.5 \mathrm{~g} \mathrm{~K}_{2} \mathrm{HPO}_{4}$ to 1 1 distilled water. The $\mathrm{pH}$ was set to 7 with $\mathrm{KOH}$. All of the components were of analytical grade, except for Na-lactate, which was of $>80 \%$ purity (Kolmert 1999) (Fig. 2).

\section{Experimental system, field scale \\ Electroremediation system}

A pit was dug at the site of the chlor-alkali factory and lined with tarpuline. Two titanium mesh electrodes measuring $0.8 * 1.2 \mathrm{~m}$ were placed at $1 \mathrm{~m}$. from each other. After installation of the electrodes, the pit was filled with homogenous soil, where stones had been 


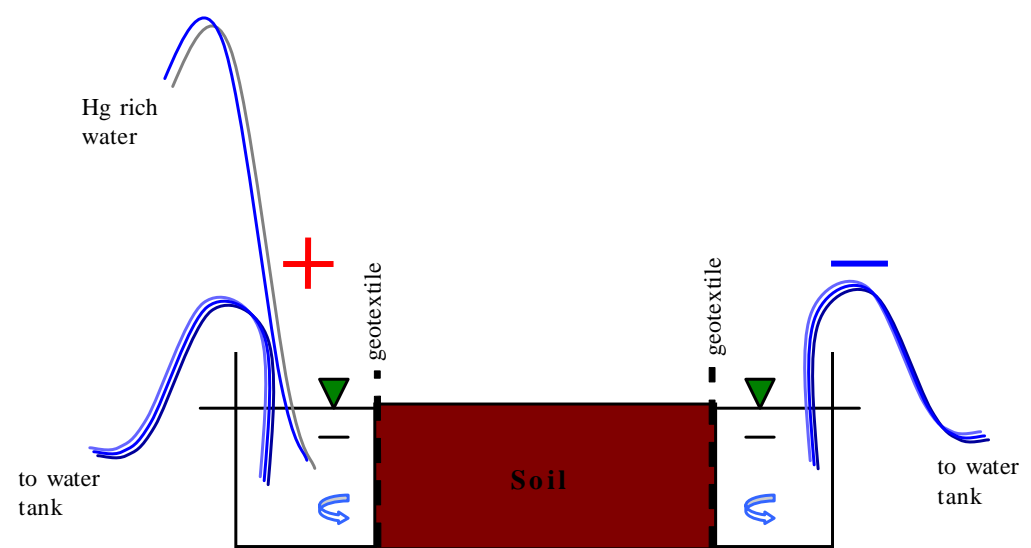

Fig. 1: Set up of soil treatment by electrokinetics. Mercury rich water from the anode is pumped to the SRB system

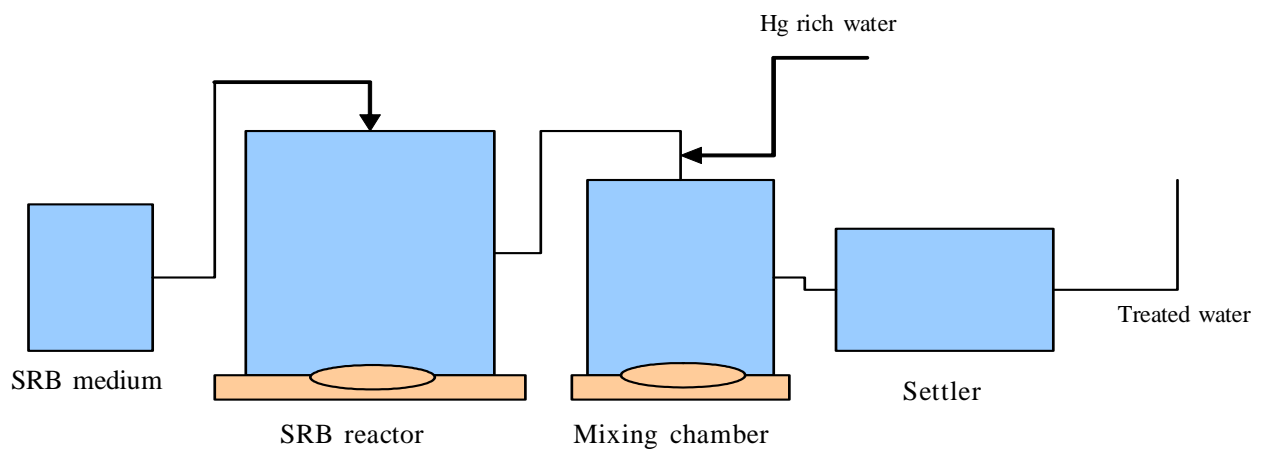

Fig. 2: Set up of $\mathrm{H}_{2} \mathrm{~S}$ production and water treatment by SRB, connecting to the left of Fig. 1

removed. Four groundwater observation wells were placed between the electrodes and two observation wells outside the electrode compartment (Fig. 3). $5 \mathrm{~kg}$ potassium iodide was mixed with an equal amount of soil and was added to 9 wells next to the cathode compartment. A current of $100 \mathrm{~V}$ was applied. After 4 days, the current was reduced to $50 \mathrm{~V}$, since high temperatures threatened to dry out the soil. The experiment was open to precipitation, but dry weather made irrigation necessary on day 9 . The total duration of the experiment was 20 days.

\section{SRB system}

A packed bed reactor with a volume of $180 \mathrm{~L}$ filled with Poravaer ${ }^{\circledR}$ giving a void volume of $100 \mathrm{~L}$ was used. The reactor was filled with $100 \mathrm{~L}$ of inoculum pre-grown in the reactor at another site. Due to the fact that an old biofilm was already established on the carriers, a new biofilm with SRB was formed within a few days. Recirculation of the liquid was done from upside to downside and the inlet was placed in the bottom of the reactor. The SRB reactor was placed in sequence with a reaction tank where the $\mathrm{H}_{2} \mathrm{~S}$ rich outflow was mixed with the $\mathrm{Hg}$ contaminated water that was continuously withdrawn from the well inside the anode (Fig. 4). The anodic water was mixed with the biogenic sulphide in a $1: 3$ ratio with a flow of $1 \mathrm{~L} /$ day of the anodic water.

\section{Sampling - Field scale}

Solution samples of $50 \mathrm{~mL}$ were taken regularly from the electrodes, observation wells, reaction chamber and settler. Mercury and redox were analyzed in all samples, iodide was analyzed in the electrode and observation well samples and sulphide in reaction chamber of the SRB system. 5 samples of the initial soil were taken during refilling of the pit. Totally, 20 soil samples were taken at the end of the experiment along two anodecathode profiles at 5 locations and two depths (30 and $70 \mathrm{~cm}$ below the surface) each. 
Table 1: Mercury concentrations $(\mu \mathrm{g} / \mathrm{L})$ and mercury reduction (\%) in the SRB system

\begin{tabular}{llll}
\hline Time (h) & Anode water & $\begin{array}{l}\text { Reaction } \\
\text { chamber } \\
\text { water }\end{array}$ & Reduction \\
\hline 0 & 0 & - & - \\
1 & 0 & - & - \\
3 & 116 & - & - \\
5 & 304 & - & - \\
7 & 373 & - & - \\
23 & 2250 & - & - \\
29 & 2560 & 16,4 & $>99.3$ \\
48 & 4310 & 10,2 & $>99.7$ \\
74 & 7270 & 10,5 & $>99.8$ \\
97 & 6840 & 4,2 & $>99.9$ \\
120 & 6490 & 5,1 & $>99.9$ \\
144 & 15400 & 4,1 & $>99.9$ \\
164 & 10300 & 3,7 & $>99.9$ \\
190 & 7940 & 0,0 & $>99.9$ \\
End & 13400 & 5,5 & $>99.9$ \\
\hline
\end{tabular}

Table 2: Mercury concentration $(\mu \mathrm{g} / \mathrm{L})$ during the field experiment and mercury reduction by the SRB (\%)

\begin{tabular}{llll}
\hline $\begin{array}{l}\text { Time } \\
\text { (days) }\end{array}$ & Anode & $\begin{array}{l}\text { Mixing } \\
\text { chamber }\end{array}$ & Reduction \\
\hline 1 & 41 & 0 & $>93.7$ \\
2 & 8130 & 511 & $>99.9$ \\
5 & 65700 & 26 & $>99.9$ \\
9 & 56100 & 21 & $>99.7$ \\
15 & 58900 & 147 & $>94.2$ \\
21 & 45600 & 2640 & $>93.7$ \\
\hline
\end{tabular}

\section{Analyses}

Soil samples were taken at the end of the experiments and digested using Aqua Regia and open focused microwave extraction (Lifvergren et al.,2000).

Mercury in extracts and water samples was analyzed by cold vapour atomic adsorption spectrometry (CVAAS) after reduction with sodium borohydride. Hydrogen peroxide was added to the pilot scale samples prior to mercury analysis to oxidize the hydrogen sulphide that was left and thus reduced the interference from it during analysis (Pott and Mattiasson 2004). pH, Eh and iodide were measured in-situ in the lab. scale and in extracted water samples in the field. Iodide was measured using an ion selective electrode. Sulphide was measured by the method described by CordRuwisch (1985). Redox was estimated using a redox electrode. The extreme redox variation in the experiments made more precise measurements unnecessary.

\section{RESULTS AND DISCUSSION}

Lab studies

Mercury was quickly mobilized at the cathode end of the setup. Mercury moved towards the anode as a mercury iodide complex, as discussed in detail by Suèr and Allard (2003) and Suèr and Lifvegren (2003). Mercury was removed less completely in the present experiment than in previous experiments, which is likely caused by the lower electric field strength (lower current density) and lower iodide concentrations in the present setup. Soil mercury content had decreased from $94 \mathrm{mg} / \mathrm{kg}$ to $72 \mathrm{mg} / \mathrm{kg}$, with most removal at the cathode side.

Mercury concentrations in the anode solution rose from 0 to $15.4 \mathrm{mg} / \mathrm{L}$. The iodide concentration in the soil water was up to $0.8 \mathrm{mM}(100 \mathrm{mg} / \mathrm{L})$, but decreased in the anode solution due to oxidation to iodine. The $\mathrm{pH}$ of the anode solution decreased from initially 6 to vary between $\mathrm{pH} 2$ and 4, due to the dissociation of water. The anode solution was transferred through tubings to the reaction chamber where the water was mixed with a $\mathrm{H}_{2} \mathrm{~S}$ stream from the bioreactor. While mercury concentrations in the anode compartment increased from 0 to $15400 \mu \mathrm{g} / \mathrm{L}$, concentrations in the outflow from the reaction chamber were below $20 \mu \mathrm{g} / \mathrm{L}$ in the beginning and less than $5 \mu \mathrm{g} / \mathrm{L}$ at the end of the experiment (Table 1 ).

The lab. studies clearly showed that the setup of electro-remediation and sulphide precipitation in sequence was functional. The obtained precipitation down to $5 \mu \mathrm{g} / \mathrm{L}$ corresponds to a precipitation efficiency of $>99.9 \%$. Concentrations in the sedimentation chamber were slightly higher, likely due to the time lag between the reaction and sedimentation chamber and possibly oxygen leakage.

\section{Field studies}

Soil treatment

The $100 \mathrm{~V}$ electric field initially resulted in a current of $13 \mathrm{~A}$.

The current increased to $25 \mathrm{~A}$ on the fifth day and when the electric field was decreased to $50 \mathrm{~V}$, the current fell to vary between 7 and $11 \mathrm{~A}$.

The $\mathrm{pH}$ in the anode decreased to 1 and the cathode increased to 13. 


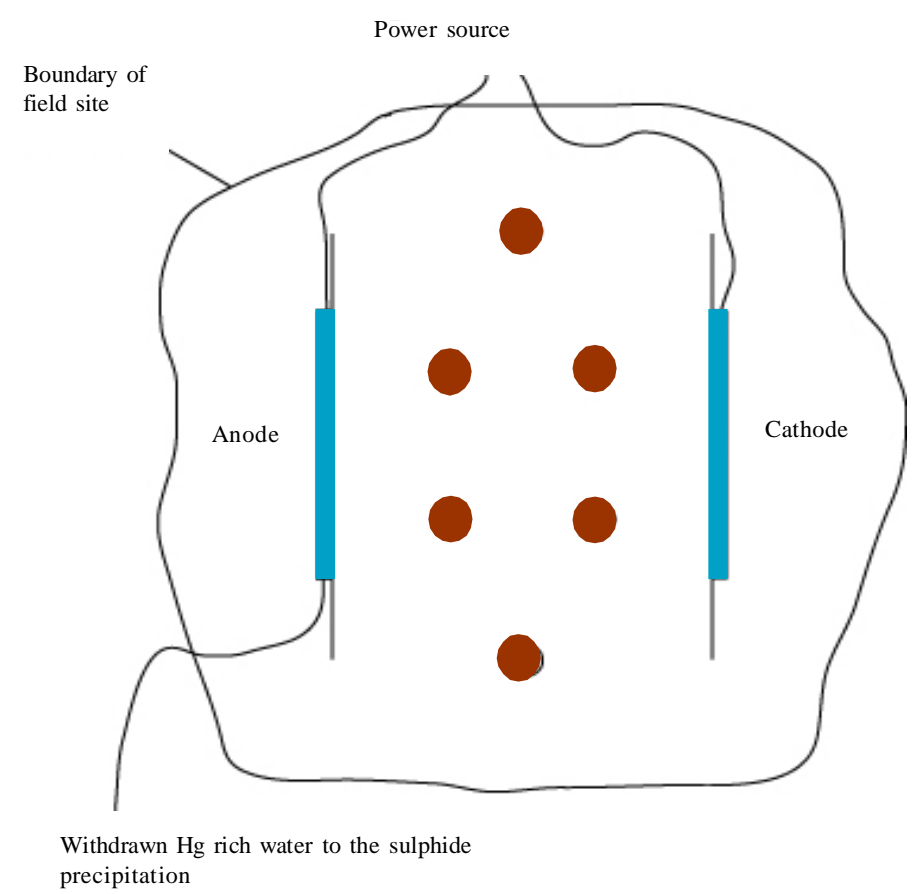

Fig. 3: Pilot setup of soil treatment. Cirkels denote groundwater sampling tubes

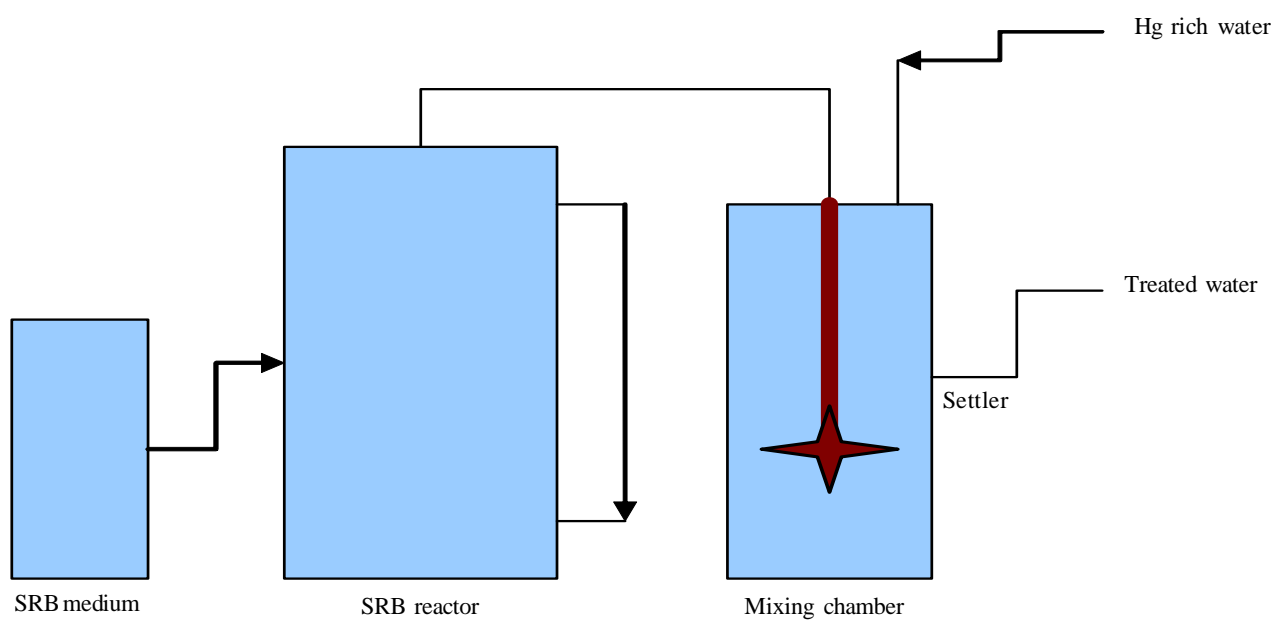

Fig. 4: Pilot setup for $\mathrm{H}_{2} \mathrm{~S}$ production and precipitation of $\mathrm{HgS}$

The $\mathrm{pH}$ in the groundwater was 7 until day 9. On the ninth day, $\mathrm{pH}$ increased to 9.5 in the well closest to the cathode. On day 15, pH near the cathode increased further to 12.7 and groundwater closest to the anode had $\mathrm{pH} 2.9$ (25 cm from anode) and 4.9 (30 cm from anode). Soil pH, after 21 days, was 6.5 nearest the anode and 11.6 nearest the cathode. Redox was strongly oxidative in the anode $(+1000 \mathrm{mV})$ and reducing in the catode $(-500 \mathrm{mV})$. The groundwater redox was initially $+100 \mathrm{mV}$ but a gradient developed and steepened during the experiment, so that after 21 days redox potential in the groundwater ranged from $+660 \mathrm{mV}$ 
nearest the anode to $-350 \mathrm{mV}$ nearest the cathode. Iodide concentrations started at $1200 \mathrm{mg} / \mathrm{L}$ in the cathode and decreased to $<2 \mathrm{mg} / \mathrm{L}$. Iodide in the soil varied between 0 and $790 \mathrm{mg} / \mathrm{L}$. The highest concentrations were measured on day 5 when the soil water was the lowest. The subsequent irrigation decreased the iodide concentrations somewhat. Iodide in the anode was $<1 \mathrm{mg} / \mathrm{L}$ throughout the experiment.

Mercury in the anode, cathode and groundwater was $<1300 \mu \mathrm{g} / \mathrm{L}$ before the electric field was applied. Groundwater concentrations varied substantially during the experiment with concentrations between 30 and $6500 \mu \mathrm{g} / \mathrm{L}$. Concentrations in the cathode were low: $<300 \mu \mathrm{g} / \mathrm{L}$. Concentrations in the anode increased quickly to 66,000 on day 5 and then slowly decreased to $46,000 \mu \mathrm{g} / \mathrm{L}$ on day 21 .

The removal of mercury to the anodic solution was not visible in the soil samples. Mercury concentration in the soil initially varied between 85 and $97 \mathrm{mg} / \mathrm{kg}$. When the electric field was shut off, mercury concentrations ranged from 32 to $156 \mathrm{mg} / \mathrm{kg}$, with no discernable trend between anode and cathode.

To sum up, the anode solution that was pumped to the SRB system reaction chamber was very acidic $(\mathrm{pH}$ 0.8-1.7) and strongly oxidizing $(\mathrm{Eh}+1000 \mathrm{mV})$ with high mercury concentration (Hg ca $60000 \mu \mathrm{g} / \mathrm{L}$ ) and low iodide $(<1 \mathrm{mg} / \mathrm{L})$.

\section{Water treatment / Mercury sulphide precipitation}

Sulphide concentrations in the reaction chamber started at $1.9 \mathrm{mM}$. The concentration steadily increased and was $10 \mathrm{mM}$ at the end of the experiment. The concentration in the mixing chamber at the end of the experiment was out of range for the calibration curve for the method used. However, the achieved values suggested below $1 \mathrm{mM}$. $\mathrm{pH}$ in the reaction chamber was 7.5 to 7.7 and varied in the mixing chamber from 6.4 to 4.3.

Mercury concentrations in the mixing chamber started at $511 \mu \mathrm{g} / \mathrm{L}$ on the first day, probably due to particle stirr-up from the installation. Mercury subsequently fell to $<30 \mu \mathrm{g} / \mathrm{L}$, which corresponds to $>98 \%$ removal of mercury from the solution (Table 2 ).

On day 20, at the end of the experiment, the mercury concentration rose to $2640 \mu \mathrm{g} / \mathrm{L}$ in the mixing chamber (94\% removal of mercury). This was probably due to increasing redox potential. The increased from $-120 \mathrm{mV}$ (on day 4) to $342 \mathrm{mV}$ (on day 20). The rise in redox hinders the precipitation of mercury sulphide (Svensson et al.,2006a; Svensson et al., 2006b). The redox increase is due to the steady input of highly oxidative water from the anode, but may also have been influenced by some leakage of air into the system where the mixer was inserted.

Sulphate reducing bacteria succeeded in treating water from electro-remediation. The water was highly oxidic at extremely low $\mathrm{pH}$ and contained both iodide and iodine (in the lab. experiments). Iodide and tri-iodide are strong complexing agents for mercury and compete with sulphide for mercury, which could have hindered the precipitation of mercury sulphide. Iodine is a strong oxidising agent and together with the oxidizing characteristics of the anode solution sulphide could have been oxidized to sulphate. This would hinder the sulphide from precipitating mercury. In both the laboratory set-up and the field experiment, the mercury was successfully removed from the anode solution using SRBs.

The mobilization by electro-remediation connected with a sulphide precipitation step has shown to have a great potential. The output of mercury in the field was not environmentally acceptable (in spite of the high removal rate), but with a better control of the redox potential, this could be improved significantly. This is suggested by the influence of redox on the field precipitation and by the laboratory studies where values of less than $5 \mu \mathrm{g} / \mathrm{L}$ were achieved.

The precipitation of the mobilized mercury worked well and with further improvement of the precipitation steps with regard to maintaining a low redox potential, this method will be a well suited setup to treat mercury contaminated soils.

\section{ACKNOWLEDGEMENTS}

The authors wish to thank the personnel of the chlor-alkali plant, who have been the most helpful during the field experiment and to Andreas Bengtsson for his help with the laboratory experiment. The COLDREM program supported by the Swedish Strategic Fund for Environmental Research (Mistra) and the Knowledge foundation supported this project. The laboratory work was executed at Örebro University's laboratory supported by SAKAB.

\section{REFERENCES}

Acar, Y. B.; Alshawabkeh, A. N., (1993). Principles of electrokinetic remediation. ES\&T. 27(13), 2638-2647.

Alvarez, M. T.; Pozzo, T.; Mattiasson, B., (2006). Enhancement of sulphide production in anaerobic packed 
bed bench-scale biofilm reactors by sulphate reducing bacteria. Biotechnol. Lett., 28 (3), 175-181.

Barnes, L. J., (1994). Emerging technology for bioremediation of metals. J. L. Means and R. E. Hinchee. Boca Raton, Lewis Public Cop., 39-43.

Cord-Ruwisch, R., (1985). A quick method for the determination of dissolved and precipitated sulfides in cultures of sulfate-reducing bacteria. J. Microbiol. Methods 4, 33-36.

Cox, C. D.; Shoesmith, M. A.; Ghosh, M. M., (1996). Electrokinetic remediation of mercury-contaminated soils using iodine/iodide lixiviant. Environ. Sci. Technol., 30 (6), 1933-1938.

Håkansson, K.; Mattiasson, B., (2002). Microbial degradation of acetonitrile using a suspended-carrier biofilm process. Biotechnol. Lett., 24 (4), 287-291.

Hamilton, W. A., (1998). Sulfate-reducing bacteria: Physiology determines their environmental impact. Geomicrobiol. J., 15 (1), 19-28.

Hansen, T. A., (1994). Metabolism of sulfate-reducing prokaryotes. Antonie van Leeuwnhoek, 66 (1-3), 165-185.

Ho, S. V.; Athmer, C.; Sheridan, P. W.; Hughes, B. M.; Orth, R.; McKenzie, D.; Brodsky, P. H.; Shapiro, A. M.; Sivavec, T. M.; Salvo, J.; Schultz, D.; Landis, R.; Griffith, R.; Shoemaker, S., (1999). The lasagna technology for in situ soil remediation 2 Large field test. Environ. Sci. Technol., 33 (7), 1092-1099.

Jorgensson, B. B., (1982). Ecology of the bacteria of the sulphur cycle with special reference to anoxic-oxic interface environments. Philosophical Transactions of the Royal Society of London. Series B: Bio. Sci., 298 (1093), 543-561.

Khan, F. I.; Husain, T.; Hejazi, R., (2004). An overview and analysis of site remediation technologies. J. Environ. Manage., 71(2), 95-122.

Kolmert, A., (1999). Sulfate-reducing bacteria in bioremediation processes. Lund, Lund University.

Kolmert, Å.; Henrysson, T.; Hallberg, R.; Mattiasson, B., (1997). Optimization of sulphide production in an anaerobic continuous biofilm process with sulphate reducing bacteria. Biotechnol. Lett. 19 (10), 971-975.

Lageman, R.; Pool, W., (2001). Thirteen years electroreclamation in the Netherlands. EREM $2001-3^{\text {rd. }}$ Symposium and status report on electrokinetic remediation, Karlsruhe, Germany, Angewandte Geologi Karlsruhe.

Lifvergren, T., (2001). Remediation of mercury polluted soil. Örebro studies in Environmental science 1. Örebro, Sweden, Örebro University.

Lifvergren, T.; Suer, P.; Wievegg, U., (2000). Microwaveassisted digestion of mercury polluted soil. $11^{\text {th. }}$ Annual international conference on heavy metals in the Environment, University of Michigan, School of Public Health, Ann Arbor, MI, USA (CD-ROM).

Lloyd, J. R.; Klessa, D. A.; Parry, D. L.; Buck, P.; Brown, N. L., (2004). Stimulation of microbial sulphate reduction in a constructed wetland: microbiological and geochemical analysis. Water Res., 38 (7), 1822-1830.

Monhemius, A. J., (1977). Precipitation diagrams for metal hydroxides, sulphides, arsenates and phosphates. Transactions of the institutions of mining and metallurgy section C-Mineral processing and extractive metallurgy: C202- C206.
Monserrate, E.; Häggblom, M. M., (1997). Dehalogenation and biodegradation of brominated phenols and bezoic acids under Iron-Reducing, Sulfidogenic and Methanogenic Conditions. Appl. Environ. Microbiol., 63 (10), 39113915.

Naturvårdsverket, (1997). Slutförvar av kvicksilver (Final disposal of mercury). Stockholm, Naturvårdsverket.

Pott, B. M.; Mattiasson, B., (2004). Separation of heavy metals from water solutions at the laboratory scale. Biotechnol. Lett., 26 (5), 451-456.

Probstein, R. F.; Hicks, R. E., (1993). Removal of contaminant from soils by electric fields. Science, 260 (5107), 498-503.

Reddy, K. R.; Xu, C. Y.; Chinthamreddy, S., (2001). Assessment of electrokinetic removal of heavy metals form soils by sequential extraction analysis. J. Hazar. Mater. 84 (2), 279-296.

Suer, P.; Allard, B., (2003). Mercury transport and speciation during electrokinetic soil remediation. Water, Air, Soil Pollut., 143 (1-4), 99-109.

Suer, P., Gitye, K.; Allard, B., (2003). Speciation and transport of heavy metals and macroelements during electroremediation. Environ. Sci. Technol., 37 (1), $177-$ 181.

Suer, P.; Lifvergren, T., (2001). Electrokinetic remediation of mercury contaminated soil with iodide addition. $6^{\text {th. }}$ International conference on mercury as a global pollutant, Minamata Japan.

Suer, P.; Lifvergren, T., (2003). Mercury contaminated soil remediation by iodide and electroreclamation. J. Environ. Eng., 129 (5), 441-446.

Swedish governmental bill, (1997/98). Nr 145.

Svensson, M.; Allard, B.; Düker, A., (2006a). Formation of $\mathrm{HgS}$ - mixing $\mathrm{HgO}$ or elemental Hg with $\mathrm{S}$, FeS or FeS2. Sci. Total Environ. 368 (1), 418-423.

Svensson, M.; Düker, A.; Allard, B., (2006b). Formation of cinnabar - estimation of favourable conditions in a proposed Swedish repository. J. Hazard. Mater., B136 (3), 830-836. van Houten, R. T.; Pol, L. W. H.; Lettinga, G., (1994). Biological sulphate reduction using gas-lift reactors fed with hydrogen and carbon dioxide as energy and carbon source. Biotechnol. Bioeng., 44 (5), 586-594.

Webb, J. S.; McGinness, S.; Lappin-Scott, H. M., (1998). Metal removal by sulphate-reducing bacteria from natural and constructed wetlands. J. Appl. Microbiol., 84 (2), 240-248. 


\section{AUTHOR (S) BIOSKETCHES}

Håkansson, T., M.Sc., Ph.D. student at the Department of Biotechnology, Lund University, Sweden, researching the clean up of waste water by the use of sulphate reducing bacteria. He works currently at Malmö City, Sweden. Email: torbjorn.hakansson@biotek.lu.se

Suer, P., MSc, PhD, researcher at the Department of Geomaterials and Modelling, Swedish Geotechnical Institute, SE 58193 Linköping, Sweden and studied electrokinetic remediation as a part of her PhD studies at Man-Technology-Environment Research Center, Örebro University, Sweden. Email: pascal.suer@swedgeo.se

Mattiasson, B., Professor, Department of Biotechnology, Lund University, Sweden.

Email: bo.mattiasson@biotek.lu.se

Allard, B., Professor of chemistry at the Department of Natural Sciences at Örebro University and the head of Man-Technology-Environment Research Centre, Örebro University, Sweden. Email: bert.allard@nat.oru.se.

This article should be referenced as follows:

Håkansson, T., Suer, P., Mattiasson, B., Allard, B., (2008). Sulphate reducing bacteria to precipitate mercury after electrokinetic soil remediation. Int. J. Environ. Sci. Tech., 5 (2), 267-274. 